Federal Reserve Bank of Minneapolis

Research Department

\title{
Dynamics of the Trade Balance in Theory and Practice
}

\author{
David K. Backus and Patrick J. Kehoe*
}

Working Paper 323

Revised September 1995

\begin{abstract}
We examine deviations from trend of net exports and other components of GNP for the United States and attempt to build models consistent with their behavior. The most striking fact is that net exports have consistently been countercyclical. We show, first, that dynamic pure-exchange models can only produce a negative correlation between net exports and GNP if the variance of consumption exceeds that of output. In the United States it does not, so this class of models cannot explain observed comovements between output and trade. We then examine government spending and nontraded goods as potential remedies, but show that their behavior is either inconsistent with the data or can be made consistent with any pattern of comovements. The most promising model introduces production and capital formation. Fluctuations are driven by countryspecific productivity shocks, in which high productivity domestically leads to high domestic investment and a deficit in the balance of trade. This theory also receives support from the large negative covariance between net exports and investment in American data.
\end{abstract}

Keywords: risk sharing, competitive equilibrium, government deficits, nontraded goods, investment, productivity

JEL classification numbers: $431,131,441$

*Backus, Federal Reserve Bank of Minneapolis and Queen's University; Kehoe, Federal Reserve Bank of Minneapolis and University of Minnesota. Backus thanks the SSHRC of Canada for financial support. Both authors thank Dennis Podlesak for guidance and encouragement. The views expressed herein are those of the authors and not necessarily those of the Federal Reserve Bank of Minneapolis or the Federal Reserve System. 


\section{Introduction}

What determines the dynamic behavior, particularly at high frequencies, of the balance of trade? We suggest that fluctuations in investment, driven by country-specific productivity shocks, may be the answer. The idea has much of the flavor of Sachs (1981). Our analysis, however, has more in common with the dynamic competitive models described by Lucas, Prescott, and Stokey (1986) and used in open economy macroeconomics by, among many others, Helpman and Razin (1982, 1984, 1985), Stockman and Svensson (1985), and Kehoe (1986). Unlike some of these papers we consider only real models. We also restrict ourselves, for the most part, to models with a single good per period. This eliminates the intratemporal relative prices so dear to international economists, but has the great advantage of focusing our attention on intertemporal decisions.

Our theoretical world is a dynamic economy with many consumers and production techniques. A country is a utility function, a production technique, and some claims on the world's resources. Allocations of goods and factors are determined in competitive equilibrium. We make repeated use of the equivalence between Pareto optima and competitive equilibria in these economies and derive equilibria as solutions to planning problems.

We build toward the investment/productivity hypothesis gradually. Section 2 reports highfrequency comovements between net exports and components of GDP in the United States over the past 30 years. Net exports, somewhat to our surprise, is quite strongly inversely correlated with GDP. This correlation is reflected in both consumption and investment, but since the latter is considerably more variable its covariance with net exports is larger. Section 3 considers exchange economies, in which countries trade to smooth idiosyncratic fluctuations in their endowments. We point out that since consumption is less volatile than output in American data, these models cannot mimic observed comovements of consumption, output, and net exports. We use this section to explore the sources of this empirical difficulty and to develop the use of planning problems in 
deriving competitive equilibria. We also point out that models driven by different rates of time preference are low-frequency models: they explain trends in consumption and net exports, but not high-frequency fluctuations.

Sections 4 and 5 examine government finance and nontraded goods as potential factors explaining trade balances. We show that government purchases of goods and services have been virtually independent of net exports over the postwar period. Government deficits have been correlated slightly with net exports, primarily because tax revenues are strongly procyclical. Models with nontraded goods suffer from the same defect as other exchange models: they cannot generate negative comovements between output and net exports when consumption is less variable than output. We also show that by choosing the stochastic specification of the endowment of nontraded goods appropriately, we can generate any pattern of comovements between output and trade. Without separate data on traded and nontraded goods, the theory lacks empirical content.

Investment is introduced in Section 6. Countries are associated with production functions which transform current output into future output using "capital." These functions are subjected to shocks in productivity that vary stochastically over time. We argue, largely by example, that persistent productivity shocks can produce the large fluctuations in investment and negative comovements between output and net exports apparent in American data. The theory requires very concave utility functions and not so concave production functions. The difficulty of obtaining analytical solutions in these models is a strong argument for numerical simulation along Kydland and Prescott (1982) lines.

\section{The Cyclical Behavior of Trade in the United States}

We report in Table 1 a number of statistics describing cyclical movements of the components of GDP and other variables in the United States over the last 30 years. Each series has been 
detrended with the Hodrick and Prescott (1978) high-pass filter. Most of the table replicates the salient features of business cycles familiar to readers of Hodrick and Prescott (1978), Kydland and Prescott (1982, Table 3), and Prescott (1983, Table 1; 1986, Table 1): investment is two to three times more volatile, in percentage terms, than output and consumption of nondurables and services is about half as volatile. Both investment and consumption are strongly autocorrelated and covary positively with output.

More interesting for our purposes is the strong negative correlation between net exports and output evident in Table 1 and Figure 1. Relative to trend, the United States has consistently run deficits in booms, surpluses in recessions (imports vs. exports). The pattern appears in both exports and imports individually, but imports are more strongly correlated than exports with output. The contemporaneous correlation of net exports with components of GDP (see Table 2) appears most strongly in consumption and investment. Government purchases of goods and services are virtually uncorrelated with net exports, but the federal government deficit, which includes taxes and transfers, is quite strongly correlated with trade deficits. Most of this correlation arises from the revenue side of the governments financial statement.

\section{Trade Dynamics in Exchange Economies}

We start with exchange economies in which trade is generated by differences in endowments across countries. The essential ingredient is the smoothing associated with convex preferences: consumers, whom we refer to as countries, attempt to smooth their consumption streams over time and across states of nature by importing when their endowments are low and exporting when they are high. The concept is widely used in economic theory and has a great deal of empirical support. The suggestion that the trade surplus covaries positively with output, however, is contradicted, at least at high frequencies, by the evidence of the previous section. We present a series of models, 
illustrated by examples, to explain the source of this empirical difficulty and suggest possible remedies. We argue that one popular model is best viewed as an explanation for low-frequency movements and has the same implications for high frequencies as those suggested by the smoothing argument.

In our economics countries trade a single good whose quantity varies stochastically over time and across states. Country $i(i=1,2, \ldots, I)$ is endowed with $y_{s, t}^{i}$ units of the good in state $s$ at date $t$. The aggregate endowment is $\mathrm{Y}_{\mathrm{s}, \mathrm{t}}=\sum_{\mathrm{i}=1}^{\mathrm{I}} \mathrm{y}_{\mathrm{s}, \mathrm{t}}^{\mathrm{i}}$. We assume that states are independently and identically distributed over time with probabilities $\left(\mathrm{s}=0,1, \ldots, \mathrm{s}, \Sigma_{\mathrm{s}} \pi_{\mathrm{s}}=1\right)$. Because of this we need only index equilibrium quantities and prices by the current state, and not by the entire history of states. Accordingly we denote consumption quantities by $c_{s, t}^{i}$ and prices by $\mathrm{p}_{\mathrm{s}, \mathrm{t}}$. Independence also suggests a natural distinction between high and low-frequency fluctuations, as we shall see shortly. Countries' preferences are characterized by utility functions that are additively-separable over time:

(3.1) $\mathrm{U}_{\mathrm{i}}=\sum_{\mathrm{t}=0}^{\mathrm{T}}\left\{\sum_{\mathrm{s}} \pi_{\mathrm{s}} \mathrm{u}_{\mathrm{i}}\left(\mathrm{c}_{\mathrm{s}, \mathrm{t}}^{\mathrm{i}}, \mathrm{t}\right)\right\}$

with $u_{i}$ increasing and strictly concave in its first argument. The utility functions satisfy the Inada conditions,

$$
\begin{aligned}
& \lim _{c \rightarrow 0} u_{i}^{\prime}(c, t)=\infty \\
& \lim _{c \rightarrow \infty} u_{i}^{\prime}(c, t)=0
\end{aligned}
$$

for each $t$, where $u_{i}^{\prime}$ denotes the derivative with respect to the first argument. With this structure and complete markets in dated, state-contingent claims, any competitive equilibrium will specify $\mathrm{c}_{\mathrm{s}, \mathrm{t}}^{\mathrm{i}}$ and (obviously) $y_{s, t}^{i}$ as functions of $s$ and $t$. We interpret dependence on $s$ as high-frequency movements, analogous to those examined in Tables 1 and 2, and dependence on $\mathrm{t}$ as trend. 
We now have more than enough structure to say something about the covariance of net exports with domestic output. Net exports in this economy is defined by

$$
n x_{s, t}^{i}=y_{s, t}^{i}-c_{s, t}^{i} .
$$

Given $t$, all three quantities are random variables dependent on $s$. The covariance between highfrequency movements in net exports and output can be decomposed into

$$
\operatorname{cov}\left(n x^{i}, y^{i}\right)=\operatorname{var}\left(y^{i}-c^{i}, y^{i}\right)=\operatorname{var}\left(y^{i}\right)-\operatorname{cov}\left(c^{i}, y^{i}\right)
$$

(The notation is intended to suggest variation in $n x^{i}, y^{i}$, and $c^{i}$ due to $s$ for given t.) A sufficient condition for this covariance to be positive is that the variance of output exceed that of consumption. This condition holds for the United States so the model's prediction is falsified by the data. We state this result now to emphasize that it arises largely from the definition of net exports in an exchange economy, and does not depend on any special features built into the models to follow.

The following proposition characterizes prices and quantities in a competitive equilibrium under fairly general conditions:

Proposition 1 (Equilibrium in exchange economies). In the exchange economy with additively separable preferences, a competitive equilibrium is characterized by functions $\mathrm{g}_{i}$, one for each country, and h such that

$$
c_{s . t}^{i}=g_{i}\left(Y_{s, t}, \lambda, t\right)
$$

(ii) $\quad \mathrm{p}_{\mathrm{s}, \mathrm{t}}=\pi_{\mathrm{s}} \mathrm{h}\left(\mathrm{Y}_{\mathrm{s}, \mathrm{t}}, \lambda, \mathrm{t}\right)$

for some choice of "welfare weights" $\lambda \in\left\{\left(\lambda_{1}, \ldots, \lambda_{\mathrm{I}}\right) \mid \lambda_{\mathrm{i}}>0, \Sigma \lambda_{\mathrm{i}}=1\right\}$, and where $\mathrm{h}$ and each $\mathrm{g}_{\mathrm{i}}$ is increasing in its first argument. Furthermore, if $\mathrm{u}_{\mathrm{i}}(\mathrm{c}, \mathrm{t})=\beta^{\mathrm{t}} \mathrm{u}_{\mathrm{i}}(\mathrm{c})$, so that each country discounts the future at the same rate, then the functions $\mathrm{g}_{\mathrm{j}}$ do not depend on $\mathrm{t}$ and $\mathrm{h}$ can be factored into $h(Y, \lambda, t)=\beta^{t} h^{*}(Y, \lambda)$ 
The proposition is similar to Breeden and Litzenberger's (1978, Theorem 1). Our proof exploits the equivalence between competitive equilibria and Pareto optima in this economy. Any optimum can be computed as the solution to a planning problem of the form

$$
\max _{\left\{c_{s, t}^{\mathrm{i}}\right\}} \mathrm{W}=\sum_{\mathrm{i}} \lambda_{\mathrm{i}} \mathrm{U}_{\mathrm{i}}
$$

subject to the resource constraints

$$
\sum_{i} c_{s, t}^{i} \leq Y_{s, t}, \text { for all s, t. }
$$

Conversely, any competitive equilibrium corresponds to an optimum for some choice of $\lambda$. If we denote the Lagrange multipliers on the constraints by $\mathrm{p}_{\mathrm{s}, \mathrm{t}}$, then the first order conditions are

$$
\lambda_{\mathrm{i}} \pi_{\mathrm{s}} \mathrm{u}_{\mathrm{i}}^{\prime}\left(\mathrm{c}_{\mathrm{s}, \mathrm{t}}^{\mathrm{i}}, \mathrm{t}\right)=\mathrm{p}_{\mathrm{s}, \mathrm{t}} \text { for all } \mathrm{i}, \mathrm{s}, \mathrm{t}
$$

where $\mathrm{u}_{\mathrm{i}}^{\prime}$ denotes the derivative of $\mathrm{u}_{\mathrm{i}}$ with respect to its first argument. This implies that

$$
\lambda_{\mathrm{i}} \mathrm{u}_{\mathrm{i}}^{\prime}\left(\mathrm{c}_{\mathrm{s}, \mathrm{t}}^{\mathrm{i}}, \mathrm{t}\right)=\mathrm{p}_{\mathrm{s}, \mathrm{t}} / \pi_{\mathrm{s}}
$$

is, for any $s$ and $t$, the same for each country i. As we raise $p_{s, t} / \pi_{s}$, concavity of $u_{i}$ implies that $c_{s, t}^{i}$ falls for each country i. In equilibrium aggregate consumption is constrained by the aggregate endowment, so consumption by each country is increasing, and $\mathrm{p}_{\mathrm{s}, \mathrm{t}} / \pi_{\mathrm{s}}$, is decreasing, in the aggregate endowment. This functional dependence involves, in general, $\lambda$ and $t$ as stated in the proposition. With constant and equal discounting the first order conditions imply

$$
\lambda_{\mathrm{i}} \mathrm{u}_{\mathrm{i}}^{\prime}\left(\mathrm{c}_{\mathrm{s}, \mathrm{t}}^{\mathrm{i}}\right)=\mathrm{p}_{\mathrm{s}, \mathrm{t}} /\left(\pi_{\mathrm{s}} \beta^{\mathrm{t}}\right)
$$

so the allocation functions, $\mathrm{g}_{\mathrm{i}}$, do not depend on time and the pricing function can be expressed $\mathrm{h}(\mathrm{Y}, \lambda, \mathrm{t})=\mathrm{h}^{*}(\mathrm{Y}, \lambda) \beta^{\mathrm{t}}$. 
A direct consequence of Proposition 1 is that the stochastic behavior of trade is driven by the covariance between domestic and world output. From (3.2) we see that the covariance between net exports and domestic output, for example, depends on $\operatorname{cov}\left(\mathrm{c}^{\mathrm{i}}, \mathrm{y}^{\mathrm{i}}\right)$, which we can write as $\operatorname{cov}\left[g_{j}(Y, \lambda, t), y^{i}\right]$. For any particular equilibrium (hence any particular $\lambda$ ) and date t, this covariance is determined by the relation between $\mathrm{Y}$ and $\mathrm{y}^{\mathrm{i}}$. Since $\mathrm{g}_{\mathrm{i}}$ is increasing in $\mathrm{y}$, the covariance is positive if $\mathrm{Y}$ and $\mathrm{y}^{\mathrm{i}}$ are positively correlated. An extremely strong positive correlation may make this term large enough $\operatorname{cov}\left(n x^{i}, y^{i}\right)$ to be negative.

The model also implies that consumption in one country is deterministically related to consumption in any other, since each is a monotonic function of the aggregate endowment. We show in Section 6 that a similar property holds for production economies. Example 3.4 illustrates a method of loosening this ink.

Our first two examples provide concrete illustrations of the proposition. In the first, countries have identical homothetic preferences so the solution takes a particularly simple form. The second has neither identical countries nor homothetic preferences, but retains the linear relation between domestic consumption and world output.

Example 3.1. Let $\mathrm{u}_{\mathrm{i}}(\mathrm{c}, \mathrm{t})=\beta^{\mathrm{t}}\left(\mathrm{c}^{1-\alpha}-1\right) /(1-\alpha), \alpha>0$, for all i. Then

$$
\mathrm{c}_{\mathrm{s}, \mathrm{t}}^{\mathrm{i}}=\lambda_{\mathrm{i}}^{*} \mathrm{Y}_{\mathrm{t}, \mathrm{s}}
$$

and

$$
\mathrm{p}_{\mathrm{s}, \mathrm{t}}=\pi_{\mathrm{s}} \beta^{\mathrm{t}} \mathrm{Y}_{\mathrm{t}, \mathrm{s}}^{-\alpha}
$$

where $\lambda_{\mathrm{i}}^{*}=\lambda_{\mathrm{i}}^{1 / \alpha} / \Sigma_{\mathrm{j}} \lambda_{\mathrm{j}}^{1 / \alpha}$. We can generate a negative covariance between $n x^{\mathrm{i}}$ and $\mathrm{y}^{\mathrm{i}}$ if $\operatorname{cov}\left(\mathrm{c}^{\mathrm{i}}, \mathrm{y}^{\mathrm{i}}\right)=$ $\lambda_{i}^{*} \operatorname{cov}\left(Y, y^{i}\right)$ is large enough relative to var $y^{i}$. An example is var $y^{i}=2$, var $Y=5$, $\operatorname{cov}\left(Y, y^{i}\right)=3$, and $\lambda_{i}^{*}=3 / 4$. Then $\operatorname{cov}\left(n x^{i}, y^{i}\right)=-1 / 4$. But note also that var $c^{i}=45 / 16>$ $\operatorname{var} y^{\mathrm{i}}$. 
All of this applies to any Pareto optimum. To find the solution associated with a particular distribution of wealth we use countries' budget constraints to determine the relevant choice of $\lambda$. The constraint for country i is

$$
\sum_{s, t} p_{s, t} c_{s, t}^{i}=\sum_{s, t} p_{s, t} y_{s, t}^{i}+p_{0,0} b_{0}^{i}
$$

where $\mathrm{b}_{0}^{\mathrm{i}}$ is country i's net claims on the rest of the world at date 0 , measured in units of the date- 0 state- 0 commodity. Obviously, $\Sigma_{\mathrm{i}} \mathrm{b}_{0}^{\mathrm{i}}=0$. This constraint, together with the allocation and pricing functions, implies

$$
\lambda_{\mathrm{i}}^{*}=\frac{\sum_{\mathrm{s}, \mathrm{t}} \pi_{\mathrm{s}} \beta^{\mathrm{t}} \mathrm{y}_{\mathrm{s}, \mathrm{t}}^{\mathrm{i}}+\mathrm{y}_{\mathrm{s}, \mathrm{t}}^{-\alpha} \mathrm{p}_{0,0} \mathrm{~b}_{0}^{\mathrm{i}}}{\sum_{\mathrm{s}, \mathrm{t}} \pi_{\mathrm{s}} \beta^{\mathrm{t}} \mathrm{Y}_{\mathrm{s}, \mathrm{t}}^{1-\alpha}}
$$

It should be clear that by varying $\left\{\mathrm{b}_{0}^{\mathrm{i}}\right\}$ we can support any optimal allocation (choice of $\lambda^{*}$ ) as a competitive equilibrium. With logarithmic preferences $(\alpha=1)$ the relation is particularly transparent:

$$
\lambda_{\mathrm{i}}^{*}=\lambda_{\mathrm{i}}=\sum_{\mathrm{s}} \pi_{\mathrm{s}}\left(\mathrm{y}_{\mathrm{s}, \mathrm{l}}^{\mathrm{i}} / \mathrm{Y}_{\mathrm{s}, \mathrm{t}}\right)+(1-\beta) \mathrm{p}_{0,0} \mathrm{~b}_{0}^{\mathrm{i}}
$$

With $b_{0}^{i}=0$ country i's welfare weight is just its average share of the world endowment.

Example 3.2. Let $\mathrm{u}_{\mathrm{i}}(\mathrm{c}, \mathrm{t})=\beta^{\mathrm{t}}\left[-\alpha_{\mathrm{i}}^{-1} \exp \left(1-\alpha_{\mathrm{i}} \mathrm{c}\right)\right]$. Then an optimum is described by

$$
\begin{aligned}
& c_{s, t}^{i}=\alpha^{*} Y_{s, t}-\sum_{j \neq i} \alpha_{i}^{-1} \log \lambda_{j}, \\
& p_{s, t}=\pi_{s} \beta^{t} \exp \left[-\alpha^{*} Y_{s, t}\right] \pi_{i} \lambda_{i}^{1 / \alpha}
\end{aligned}
$$

where $\alpha^{*} \equiv\left[\Sigma_{\mathrm{i}} \alpha_{\mathrm{i}}^{-1}\right]^{-1}$. The qualitative features are the same as Example 1 .

We now turn to models in which the time dependence of utility takes the form of discounting, but allow discount factors to differ across countries. The case of different discount factors has been used in the international finance literature by Helpman and Razin $(1982,1984,1985)$, Frenkel and Razin (1985), and others in a variety of contexts. Our view is that while these models may explain 
long term trends in consumption, net exports, and so on, they do not explain the high-frequency comovements that we are interested in. Proposition 2 describes a well-known feature of these models relevant to this discussion.

PROPOSITION 2 (Equilibrium with different discount factors). Consider the exchange economy with preferences

$$
\mathrm{U}_{\mathrm{i}}=\sum_{\mathrm{t}=0}^{\infty} \beta_{\mathrm{i}}^{\mathrm{t}}\left\{\sum_{\mathrm{s}} \pi_{\mathrm{s}} \mathrm{u}_{\mathrm{i}}\left(\mathrm{c}_{\mathrm{s}, \nu}^{\mathrm{i}}\right)\right\}, \quad 0<\beta_{\mathrm{i}}<1
$$

for each country $\mathrm{i}$, where $\mathrm{u}_{\mathrm{i}}$ is increasing and strictly concave and satisfies the Inada conditions. Let $I^{*}$ be the set of countries with maximal discount factors:

$$
\mathrm{I}^{*}=\left\{\mathrm{i} \mid \beta_{\mathrm{i}}=\max \left(\beta_{1}, \beta_{2}, \ldots, \beta_{\mathrm{I}}\right)\right\} .
$$

Then for any $i$ not in $I^{*}, \lim _{t \rightarrow \infty} g^{i}(y, \lambda, t)=0$.

The point of this proposition is that different discount factors induce trends in consumption paths that can be used to explain long-run or low-frequency comovements between consumption and net exports. In a typical example, an impatient country (that is, one with low $\beta$ ) will initially consume more than its endowment, on average, but net exports gradually rise and converge to domestic output. We can think of this as an extreme version of the persistent, low-frequency movements in the trade balance apparent in long time series. The United States, for example, ran deficits for most of the 19th century.

The proof is direct. With discounting the first-order conditions for the planning problem imply

$$
\lambda_{\mathrm{i}} \beta_{\mathrm{i}}^{\mathrm{i}} \mathrm{u}_{\mathrm{i}}^{\prime}\left(\mathrm{c}_{\mathrm{s}, \mathrm{i}}^{\mathrm{i}}\right)=\mathrm{p}_{\mathrm{s}, \mathrm{t}} / \pi_{\mathrm{s}}
$$

for all countries i. Since aggregate income has the same distribution at every date, any country with less-than-maximal $\beta$ must have marginal utility increasing to maintain equality of $\lambda_{\mathrm{i}} \beta_{\mathrm{i}}^{\mathrm{i}} \mathrm{u}_{\mathrm{i}}^{\prime}\left(\mathrm{c}_{\mathrm{s}, t}^{\mathrm{i}}\right)$ across 
countries. The Inada conditions guarantee that as marginal utility rises consumption falls, reaching zero in the limit.

Example 3.3. Let $\mathrm{u}_{\mathrm{i}}(\mathrm{c}, \mathrm{t})=\beta_{\mathrm{i}}^{\mathrm{t}} \log \mathrm{c}$. Then an equilibrium allocation is

$$
\mathrm{c}_{\mathrm{s}, \mathrm{t}}^{\mathrm{i}}=\left\{\lambda_{\mathrm{i}} \beta_{\mathrm{i}}^{\mathrm{t}} / \sum_{\mathrm{j}} \lambda_{\mathrm{j}} \beta_{\mathrm{j}}^{\mathrm{t}}\right\} \mathrm{Y}_{\mathrm{s}, \mathrm{t}}
$$

with prices

$$
\mathrm{p}_{\mathrm{s}, \mathrm{t}}=\pi_{\mathrm{i}}\left(\sum_{\mathrm{i}} \lambda_{\mathrm{i}} \beta_{\mathrm{i}}^{\mathrm{t}}\right) / \mathrm{Y}_{\mathrm{s}, \mathrm{t}} .
$$

The mean of consumption across states is a declining fraction of the mean world endowment for any country with less-than-maximal discount factor. The same is true for mean net exports. With logarithmic preferences variations about this deterministic trend are the same as the identical discount factor case.

Of course a similar mechanism can be used to generate high-frequency movements in trade. The following example illustrates this for the case of logarithmic preferences. It also suggests a method of eliminating the deterministic relation between consumption in different countries that characterized our previous models.

Example 3.4. Let $\mathrm{u}_{\mathrm{i}}\left(\mathrm{c}_{\mathrm{s}, \mathrm{i}}^{\mathrm{i}}, \mathrm{t}\right)=\beta^{\mathrm{t}} \theta_{\mathrm{s}}^{\mathrm{i}} \log \mathrm{c}_{\mathrm{s}, \mathrm{t}}^{\mathrm{i}}$, where $\theta_{\mathrm{s}}^{\mathrm{i}}$ depends on the state and is, like s, independently and identically distributed over time. Note that this can be given an interpretation as a random discount factor. The equilibrium is

$$
\begin{aligned}
& \mathrm{c}_{\mathrm{s}, \mathrm{t}}^{\mathrm{i}}=\left\{\lambda_{\mathrm{i}} \theta_{\mathrm{s}}^{\mathrm{i}} / \sum_{\mathrm{j}} \lambda_{\mathrm{j}} \theta_{\mathrm{s}}^{\mathrm{i}}\right\} \mathrm{Y}_{\mathrm{s}, \mathrm{t}} \\
& \mathrm{p}_{\mathrm{s}, \mathrm{t}}=\pi_{\mathrm{s}} \beta^{\mathrm{t}}\left\{\sum_{\mathrm{i}} \lambda_{\mathrm{i}} \theta_{\mathrm{s}}^{\mathrm{i}}\right\} / \mathrm{Y}_{\mathrm{s}, \mathrm{t}} .
\end{aligned}
$$


Consider, for example, a world with two countries and two states parameterized as follows:

$$
\begin{array}{ccccccc}
\text { state(s) } & \pi_{\mathrm{s}} & \mathrm{y}_{\mathrm{s}, \mathrm{t}}^{1} & \mathrm{y}_{\mathrm{s}, \mathrm{t}}^{2} & \mathrm{y}_{\mathrm{s}, \mathrm{t}} & \theta_{\mathrm{s}, \mathrm{t}}^{1} & \theta_{\mathrm{s}, \mathrm{t}}^{2} \\
1 & 1 / 2 & 1+\mathrm{a} & 1-\mathrm{a} & 2 & 1+\mathrm{b} & 1-\mathrm{b} \\
2 & 1 / 2 & 1-\mathrm{a} & 1+\mathrm{a} & 2 & 1-\mathrm{b} & 1+\mathrm{b}
\end{array}
$$

with $0<\mathrm{a}, \mathrm{b}<1$. The solution with $\lambda_{1}=\lambda_{2}=1 / 2$ includes

$$
\begin{array}{cccc}
\text { state(s) } & \mathrm{c}_{\mathrm{s}, \mathrm{t}}^{1} & \mathrm{c}_{\mathrm{s}, \mathrm{t}}^{2} & \mathrm{tb}_{\mathrm{s}, \mathrm{t}}^{1} \\
1 & 1+\mathrm{b} & 1-\mathrm{b} & \mathrm{a}-\mathrm{b}, \\
2 & 1-\mathrm{b} & 1+\mathrm{b} & \mathrm{b}-\mathrm{a}
\end{array}
$$

so var $y^{1}=a^{2}$, var $c^{1}=b^{2}$, and $\operatorname{cov}\left(n x^{1}, y^{1}\right)=a(a-b)$, which is negative if and only if var $x^{1}<$ $\operatorname{var} c^{1}$.

This device can also be used to generate idiosyncratic fluctuations in consumption in more complex models. We consider the point made, and move on to other issues.

\section{Government Deficits and Trade Deficits}

In the last few years it has been common to attribute trade deficits to government deficits. The idea was given some credence by the strong positive correlation between these deficits in the United States during the 1980's, but it remains an open question whether fiscal policy has been the major force behind high-frequency movements in the trade deficit in the postwar period as a whole. In this section we examine the predictions of theory and compare these with American data.

We utilize a variant of the exchange economy in which government spending and taxes for country $\mathrm{i}$ are given by exogenous processes $\left\{\mathrm{g}_{\mathrm{t}, s}^{\mathrm{i}}\right\}$ and $\left\{\tau_{\mathrm{L}, \mathrm{S}}^{\mathrm{i}}\right\}$, respectively. The budget deficit of country i follows $\left\{\mathrm{d}_{t, s}^{\mathrm{i}}\right\}$ where

$$
\mathrm{d}_{\mathrm{t}, \mathrm{s}}^{\mathrm{i}}=\mathrm{g}_{\mathrm{t}, \mathrm{s}}^{\mathrm{i}}-\tau_{\mathrm{t}, \mathrm{s}}^{\mathrm{i}} .
$$


The comovements of interest concern trade deficits, $\mathrm{nm}^{\mathrm{i}}=-\mathrm{nx}$, and budget deficits, $\mathrm{d}^{\mathrm{i}}$. In what follows we assume, for simplicity only, that the period utility function is separable between private and government consumption, so that the marginal utility of private consumption does not depend on $g$.

We consider two polar cases. In the first, taxes are constant and variations in government deficits are driven solely by variations in spending. The covariance between trade deficits and government deficits reduces to $\operatorname{cov}\left(\mathrm{nm}^{\mathrm{i}}, \mathrm{g}^{\mathrm{i}}\right)$. We can easily imagine circumstances in which this covariance is positive. For example, with equal discounting and no aggregate uncertainty (in the sense that $Y_{t, s}-G_{t, s}$ is constant), Proposition 1 implies that each country's consumption is constant and

$$
\operatorname{cov}\left(n m^{i}, d^{i}\right)=\operatorname{var} g^{i}-\operatorname{cov}\left(y^{i}, g^{i}\right)
$$

Then if government spending is procyclical (or at least not too strongly countercyclical), the covariance between trade deficits and government deficits will be positive.

However, even a casual glance at the data makes it clear that variations in government spending are not behind this positive correlation. Indeed, in the same period in which trade deficits and budget deficits show a strong positive correlation, trade deficits and government purchases of goods and services show almost no correlation. In the data it appears that the correlation between trade deficits and budget deficits are due almost entirely to variations in tax revenues and in transfer payments included in federal government expenditures. This is a reflection of the fact that both tax revenues and net exports covary highly with output, and hence with each other.

In the second polar case we hold g constant and contemplate fluctuations in taxes. We show that while it is easy to build a model consistent with the hypothesis that government deficits are 
driven by variations in tax revenues, and in which these deficits covary positively with trade deficits, it is not clear what to make of it. Indeed, in our model can rationalize any correlation.

PROPOSITION 3 (The correlation between trade deficits and tax-driven government deficits is arbitrary and irrelevant). For given stochastic processes on endowments and government spending there exist stochastic processes for taxes that

(i) yield any desired correlation between trade deficits and budget deficits and

(ii) leave equilibrium consumption allocations and prices unchanged.

This proposition follows directly from the Ricardian Neutrality Theorem (see, for example, Sargent 1986). Since the equilibrium consumption allocations and prices are independent of the time path of taxes, this path can always be chosen to give the required correlation. Of course, this path is not completely arbitrary since it must satisfy the government's intertemporal budget constraint. However, given an arbitrary process for taxes that yields the desired correlation we can always adjust its mean to satisfy the intertemporal budget constraint without affecting the correlation.

\section{Dynamics With Nontraded Goods}

A second variant of the exchange economy includes nontraded goods. Since fluctuations in endowments of nontraded goods are not diversible across countries, they give us an extra degree of freedom in generating comovements among net exports, output, and government deficits. We shall see that there is a sense in which they give us too much freedom.

For this section let $\left\{\mathrm{y}_{\mathrm{Ts}, \mathrm{t}}^{\mathrm{i}}\right\}$ and $\left\{\mathrm{y}_{\mathrm{Ns}, \mathrm{i}}^{\mathrm{i}}\right\}$ denote the endowments of traded and nontraded goods of country i's residents. Let $\left\{\mathrm{c}_{\mathrm{Ts},\}}^{\mathrm{i}}\right\}$ and $\left\{\mathrm{c}_{\mathrm{Ns}, \mathrm{i}}^{\mathrm{i}}\right\}$ denote consumption of these goods and $\left\{\mathrm{q}_{\mathrm{s},\}}^{\mathrm{i}}\right\}$ the relative price of traded to nontraded goods. Assume, for simplicity only, that the period utility function is separable between these goods so that 


$$
\mathrm{u}_{\mathrm{i}}\left(\mathrm{c}_{\mathrm{Ts}, t}^{\mathrm{i}}, \mathrm{c}_{\mathrm{Ns}, t}^{\mathrm{i}}\right)=\mathrm{u}_{\mathrm{i}}^{\mathrm{T}}\left(\mathrm{c}_{\mathrm{Ts}, t}^{\mathrm{i}}\right)+\mathrm{u}_{\mathrm{i}}^{\mathrm{N}}\left(\mathrm{c}_{\mathrm{Ns}, t}^{\mathrm{i}}\right) .
$$

Before discussing correlations we must define net exports and output for this multigood economy. In any equilibrium the consumption of nontraded goods in each country is equal to the endowment of these goods: that is, $\mathrm{c}_{\mathrm{Ns}, \mathrm{t}}^{\mathrm{i}}=\mathrm{y}_{\mathrm{Ns}, \mathrm{t}}^{\mathrm{i}}$ for all $\mathrm{i}, \mathrm{s}, \mathrm{t}$. Thus net exports are given by $\left\{\mathrm{nx}_{\mathrm{s}, \mathrm{t}}^{\mathrm{i}}\right\}$ where

$$
n x_{s, t}^{i}=y_{T s, t}^{i}-c_{T s, t}^{i}
$$

As for output, let $q_{0,0}^{i}$ denote the price of traded to nontraded goods at time 0 , state 0 , and define output of country i to be $\left\{\mathrm{y}_{\mathrm{s}, \mathrm{i}}^{\mathrm{i}}\right\}$ where

$$
\mathrm{y}_{\mathrm{s}, \mathrm{t}}^{\mathrm{i}}=\mathrm{y}_{\mathrm{Ts}, \mathrm{t}}^{\mathrm{i}}+\mathrm{q}_{0,0}^{\mathrm{i}} \mathrm{y}_{\mathrm{Ns}, \mathrm{t}}^{\mathrm{i}} \text {. }
$$

With these definitions the covariance between net exports and output becomes

$$
\operatorname{cov}\left(n x^{i}, y^{i}\right)=\operatorname{var}\left(y_{T}^{i}\right)-\operatorname{cov}\left(c_{T}^{i}, y_{T}^{i}\right)-q_{0,0}^{i} \operatorname{cov}\left(c_{T}^{i}, y_{N}^{i}\right)
$$

The sense in which adding nontraded goods gives us too much freedom in generating netexport-output comovements is made precise in the following proposition.

PROPOSITION 4 (With nontraded goods the correlation between net exports and output is arbitrary). Given (5.1) and any nontrivial set of stochastic processes for traded goods, there exist stochastic processes for nontraded goods that rationalize any correlation between net exports and output. The proof is straightforward. With additive separability in utility the allocation of traded goods is independent of the time path of nontraded goods. If we fix the path of traded good endowments we also fix the path of traded good consumption, but we are completely free to choose the path of nontraded goods. By choosing this path appropriately we can control $\operatorname{cov}\left(\mathrm{c}_{\mathrm{T}}^{\mathrm{i}}, \mathrm{y}_{\mathrm{N}}^{\mathrm{i}}\right)$ without affecting the other terms in (5.4). Thus we can choose $\operatorname{cov}\left(n x^{i}, y^{i}\right)$ arbitrarily. 
Introducing nontraded goods also adds a degree of freedom in explaining trade-deficit-budgetdeficit comovements. Let $\left\{\mathrm{g}_{\mathrm{T}, \mathrm{s}}^{\mathrm{i}}\right\},\left\{\mathrm{g}_{\mathrm{N}, t,}^{\mathrm{i}}\right\},\left\{\tau_{\mathrm{Ts}, t}^{\mathrm{i}}\right\},\left\{\tau_{\mathrm{Ns}, t}^{\mathrm{i}}\right\}$ denote country i's spending and taxes in traded and nontraded goods. Net exports is given by $\left\{\mathrm{nx}_{\mathrm{s}, \mathrm{i}}^{\mathrm{i}}\right\}$, where

$$
\mathrm{nx}_{\mathrm{s}, \mathrm{t}}^{\mathrm{i}}=\mathrm{y}_{\mathrm{Ts}, \mathrm{t}}^{\mathrm{i}}-\mathrm{c}_{\mathrm{Ts}, \mathrm{t}}^{\mathrm{i}}-\mathrm{g}_{\mathrm{T}, t}^{\mathrm{i}} \text {. }
$$

Net imports, $\mathrm{nm}_{\mathrm{s}, \mathrm{i}}^{\mathrm{i}}$, is just the negative of this. The government deficit is defined to be

$$
\mathrm{d}_{\mathrm{s}, \mathrm{t}}^{\mathrm{i}}-\left(\mathrm{g}_{\mathrm{T} s, \mathrm{t}}^{\mathrm{i}}-\tau_{\mathrm{Ts}, t}^{\mathrm{i}}\right)+\mathrm{q}_{0,0}^{\mathrm{i}}\left(\mathrm{g}_{\mathrm{Ns}, \mathrm{t}}^{\mathrm{i}}-\mathrm{N}_{\mathrm{Ns}, \mathrm{t}}^{\mathrm{i}}\right)
$$

and real government spending is defined to be $\left\{\mathrm{g}_{\mathrm{s}, \mathrm{i}}^{\mathrm{i}}\right\}$, where

$$
\mathrm{g}_{\mathrm{t}, \mathrm{s}}^{\mathrm{i}}=\mathrm{g}_{\mathrm{TL}, \mathrm{s}}^{\mathrm{i}}+\mathrm{q}_{0,0}^{\mathrm{i}} \mathrm{g}_{\mathrm{N}, t}^{\mathrm{i}} \text {. }
$$

In the previous section we saw that with procyclical spending and no aggregate uncertainty, spending-driven government deficits were positively correlated with trade deficits. Here, this need not be the case. Consider the case of equal discount factors, a constant endowment of traded goods, net of government spending in traded goods, and constant taxes. By Proposition 1 the consumption of traded goods is constant and the covariance between trade deficits and budget deficits is

$$
\operatorname{cov}\left(n m^{i}, d^{i}\right)=\operatorname{var}\left(g_{T}^{i}\right)-\operatorname{cov}\left(y_{T}^{i}, g_{T}^{i}\right)-q_{0,0}^{i} \operatorname{cov}\left(y_{T}^{i}, g_{N}^{i}\right) .
$$

Notice that endowments of nontraded goods play no role in this expression, although they do in (5.3). Therefore even if total government spending covaries positively with total output we can always choose the composition of output and government spending so that this covariance is anything we want. With respect to tax-driven deficits it is obvious that a result similar to Proposition 3 will hold here also.

These examples point out that adding nontraded goods give us more freedom in generating equilibrium comovements between net exports, output, and government spending. Kehoe (1986, ch. 3) makes the same point with regard to net exports and relative prices. In a sense, however, 
theories relying on nontraded goods lack empirical content: in the absence of separate data for traded and nontraded goods any pattern of aggregate comovements can be rationalized.

\section{Trade and Investment}

We think the most promising explanation for trade dynamics at business cycle frequencies lies in the behavior of investment. Investment is both highly variable and strongly correlated with output, so it is certainly the leading symptom, if not the underlying cause of the comovements of net exports and domestic production. We can make this argument more precise using the numbers in Table 1. The covariance between net exports and output decomposes into

$$
\operatorname{cov}(n x, y)=\operatorname{cov}(y-c-z-g, y)=\operatorname{var} y-\operatorname{cov}(c, y)-\operatorname{cov}(z, y)-\operatorname{cov}(g, y)
$$

where $\mathrm{z}$ is gross investment. The variance of output is about 1.8 percent. The covariance between consumption and output, expressed as a percentage of output, is approximately

$$
(0.54)(0.78)(1.1)(2.1)=0.97 \text {. }
$$

0.54 the average share of consumption in output, $(0.78$ is the correlation of $\mathrm{c}$ and $\mathrm{y}$, and 1.1 and 2.1 are the standard deviations of $\mathrm{c}$ and $\mathrm{y}$ in percentage terms). Similarly,

$$
\operatorname{cov}(\mathrm{z}, \mathrm{y})=(0.17)(0.90)(9.6)(2.1)=3.08
$$

which is clearly much more important quantitatively. Since the final component, government spending, is only slightly correlated with output at business cycle frequencies, investment is the obvious suspect in the mystery of high-frequency trade dynamics.

Building a model with investment-driven trade dynamics is not, however, as straightforward as it may seem. We start with a fairly general framework, like that of Section 3 , but with the addition of production and capital formation. We then illustrate important quantitative elements with three examples. In all of these models, fluctuations in output and investment are driven by country- 
specific productivity shocks, which raise both output and the marginal product of capital. In Examples 6.1 and 6.2 positive productivity shocks are associated with higher domestic output and, if shocks are correlated across countries, higher world output. Consumption smoothing leads to increased current investment so that the benefits of the current shock can be spread over future periods. The extent of this smoothing-and the volatility of investment-depends on the curvature of the utility and production functions (the desirability and feasibility of smoothing). We show, however, that if shocks are independent over time this mechanism is unlikely to produce large enough fluctuations in investment to make net exports covary negatively with output. Example 6.3 emphasizes persistence. With persistent shock increases in current productivity signal increases in the future productivity of capital and lead to increases in domestic investment whether or not shocks are correlated across countries. We show in a parametric example of a small economy that high degrees of persistence and less concave production functions lead to large fluctuations in investment, and therefore provide a potential explanation for the dynamics of trade.

Our framework has the following elements. Preferences are as described in Section 3. We assume that consumers in each country discount utility at the same rate, but their period utility functions may differ. With identical discount factors we can define the welfare function

(6.1) $\mathrm{W}=\mathrm{E}_{0} \sum_{\mathrm{t}=0}^{\infty} \beta^{\mathrm{t}} \mathrm{w}(\mathrm{c}, \lambda)$

where $w(c, \lambda)=\Sigma_{i} \lambda_{i} u_{i}\left(c^{i}\right)$. Technologies may also differ across countries, with gross output (including capital left from the previous period) given by

(6.2) $\mathrm{y}_{\mathrm{t}}^{\mathrm{i}}=\mathrm{f}_{\mathrm{i}}\left(\mathrm{k}_{\mathrm{t}}^{\mathrm{i}}, \theta_{\mathrm{it}}\right)$

where $\theta_{\mathrm{it}}$ is a country-specific productivity shock and $\mathrm{k}_{\mathrm{t}}^{\mathrm{i}}$ is the capital stock. We think of the dependence of technology on $\mathrm{i}$ as arising at least partly from country-specific fixed factors like labor 
and land. As in Brock and Mirman (1972) and Brock (1982), the production functions are assumed to satisfy the conditions:

$$
\mathrm{f}_{\mathrm{i}}(0, \theta)=0
$$

$\mathrm{f}_{\mathrm{i}}(\mathrm{k}, \theta)$ is increasing and concave in $\mathrm{k}$;

$$
\begin{aligned}
& \partial \mathrm{f}_{\mathrm{i}}(\mathrm{k}, \theta) / \partial \mathrm{k} \text { is increasing in } \theta \\
& \lim _{\mathrm{k} \rightarrow \infty} \partial \mathrm{f}_{\mathrm{i}}(\mathrm{k}, \theta) / \partial \mathrm{k}=\infty \\
& \lim _{\mathrm{k} \rightarrow \infty} \partial \mathrm{f}_{\mathrm{i}}(\mathrm{k}, \theta) / \partial \mathrm{k}<1
\end{aligned}
$$

for all $\mathrm{i}$ and all permissible values of $\theta$ and $\mathrm{k}$. The productivity shocks, $\theta_{\mathrm{t}}=\left(\theta_{\mathrm{t}}, \ldots, \theta_{\mathrm{I}}\right)$, are jointly Markov, with conditional distribution function $\mathrm{F}\left(\theta_{\mathrm{t}+1} \mid \theta_{\mathrm{t}}\right)$.

The timing of decisions and information revelation follows the notation. At date the social planner chooses consumption, $\mathrm{c}_{t}^{\mathrm{i}}$, and next periods capital stocks, $\mathrm{k}_{\mathrm{t}+1}^{\mathrm{i}}$, given knowledge of the current productivity shocks, $\theta_{\mathrm{t}}$. These decisions are constrained by the gross aggregate output:

(6.3) $\quad \sum_{\mathrm{i}}\left[\mathrm{c}_{\mathrm{t}}^{\mathrm{i}}+\mathrm{k}_{\mathrm{t}+1}^{\mathrm{i}}\right] \leq \mathrm{Y}_{\mathrm{t}}=\sum_{\mathrm{i}} \mathrm{f}_{\mathrm{i}}\left(\mathrm{k}_{\mathrm{t}}^{\mathrm{i}}, \theta_{\mathrm{it}}\right)$

which embodies the assumption that investment is reversible.

We now have all the ingredients of a planning problem. At each date the state is summarized by $\mathrm{s}=\left(\mathrm{Y}_{t}, \theta_{t}\right)$. We will consider decision rules that specify allocations across consumers and capital goods as stationary functions of this state. Under standard assumptions there exists a unique value function and associated decision rules. Some of the features of these rules are given in the following proposition:

Proposition 5 (Equilibrium in production economies). In the world economy described by (6.1, $6.2,6.3)$ and associated conditions, equilibrium allocations are given by the functions 
(i) $\quad c_{1}^{i}=g_{i}\left(Y_{t}, \theta_{t}\right)$

(ii)

$$
\mathrm{k}_{\mathrm{t}+1}^{\mathrm{i}}=\mathrm{h}_{\mathrm{i}}\left(\mathrm{Y}_{\mathrm{t}}, \theta_{\mathrm{t}}\right), \quad \mathrm{i}=1,2, \ldots, \mathrm{I}
$$

satisfying $\Sigma\left\{\mathrm{g}_{\mathrm{i}}(\mathrm{y}, \theta)+\mathrm{h}_{\mathrm{i}}(\mathrm{Y}, \theta)\right\}=\mathrm{Y}$, for all $\mathrm{Y}$ and $\theta$. Each of these functions is increasing in $\mathrm{Y}$, as is $\mathrm{g}(\mathrm{Y}, \theta)=\Sigma_{\mathrm{i}} \mathrm{g}_{\mathrm{i}}(\mathrm{Y}, \theta)$. We solve the problem in two stages. In the first we choose capital stocks, $\mathrm{k}_{\mathrm{t}+1}^{\mathrm{i}}$, and aggregate consumption, $\mathrm{C}_{\mathrm{t}}=\Sigma_{\mathrm{i}} \mathrm{c}_{\mathrm{i}}^{\mathrm{i}}$; in the second we allocate aggregate consumption across countries. Take the second stage first. Define

$$
\mathrm{v}(\mathrm{C}) \equiv \max _{\{\mathrm{c}\}} \sum_{\mathrm{i}} \lambda_{\mathrm{i}} \mathrm{u}_{\mathrm{i}}\left(\mathrm{c}^{\mathrm{i}}\right)
$$

subject to

$$
\sum \mathrm{c}^{\mathrm{i}} \leq \mathrm{C} .
$$

The argument used in Proposition 1 makes it clear that the solution is characterized by functions $\mathrm{g}_{\mathrm{i}}^{*}$ such that $\mathrm{c}^{\mathrm{i}}=\mathrm{g}_{\mathrm{i}}^{*}(\mathrm{C})$ and $\Sigma_{\mathrm{i}} \mathrm{g}_{\mathrm{i}}^{*}(\mathrm{C})=\mathrm{C}$. Furthermore, each $\mathrm{g}_{\mathrm{i}}^{*}$ is increasing and, given the Inada conditions, has the property $g_{i}^{*}(0)=0$. Hence $v(C) \equiv \Sigma \lambda_{i} u_{i}\left(g_{i}^{*}(C)\right)$ is increasing and concave in $C$ and satisfies the Inada conditions

$$
\begin{aligned}
& \lim _{C \rightarrow 0} v^{\prime}(C)=\infty \\
& \lim _{C \rightarrow \infty} v^{\prime}(C)=0 .
\end{aligned}
$$

In essence, linearity of the resource constraint (6.3) fixes the relative prices of the $\mathrm{c}^{\mathrm{i}} \mathrm{s}$ so they can be aggregated into a single commodity as suggested by Hicks.

The first stage involves the choice between consumption and investment, and between investment in different countries. Substituting $\mathrm{C}_{\mathrm{t}}=\mathrm{Y}_{\mathrm{t}}-\Sigma \mathrm{k}_{\mathrm{t}+1}^{\mathrm{i}}$ we can write the optimization problem in terms of the value functions, $v(Y, \theta)$ :

$$
\max _{\left\{\mathrm{k}_{\mathrm{t}+1}^{\mathrm{i}}\right\}} v\left[\mathrm{Y}_{\mathrm{t}}-\sum \mathrm{k}_{\mathrm{t}+1}^{\mathrm{i}}\right]+\beta \int \mathrm{v}\left[\sum_{\mathrm{i}} \mathrm{f}_{\mathrm{i}}\left(\mathrm{k}_{\mathrm{t}+1}^{\mathrm{i}}, \theta_{\mathrm{t}+1}\right), \theta_{\mathrm{t}+1}\right] \mathrm{F}\left(\mathrm{d} \theta_{\mathrm{t}+1} \mid \theta_{\mathrm{t}}\right) .
$$


The first-order conditions determine $k_{t+1}^{i}$. Our question, however, is how these k's vary with $Y$. The only part of the first order conditions that depends on $y$ directly is $v\left[Y_{t}-\Sigma k_{1+1}^{i}\right]$. Since $v$ is concave, the opportunity cost of raising $\mathrm{k}_{t+1}^{\mathrm{i}}$ falls with $\mathrm{Y}_{t}$, and since the benefits are not affected, $\mathrm{k}_{t+1}^{\mathrm{i}}$ rises. In short, $\mathrm{k}_{\mathrm{t}+1}^{\mathrm{i}}$ is an increasing function of $\mathrm{Y}_{\mathrm{t}}$ as stated. We know that for this kind of problem the value function is concave in $y$, and since

$$
\mathrm{V}_{\mathrm{Y}}(\mathrm{Y}, \theta)=\partial \mathrm{v}[\mathrm{g}(\mathrm{Y}, \theta)] / \partial \mathrm{Y}
$$

aggregate consumption must be increasing in Y. Clearly consumption of each country will be increasing in $\mathrm{Y}$ as well.

For our purposes, the importance of this proposition lies in what has been left out. We need more than the qualitative monotonicity properties emphasized in the properties. Without more structure we cannot make the quantitative statements demanded by our mission. We need in particular more information about the curvature of utility functions and production functions and persistence of the productivity shocks.

Consider our problem of designing a model capable of generating negative comovements between output and net exports. Net exports is defined as production minus absorption:

$$
n x_{t}^{i}=f_{i}\left(k_{t}^{i}, \theta_{i t}\right)-\left[c_{t}^{i}-k_{t+1}^{i}\right]
$$

Output is less obvious. In one interpretation we assume, contrary to fact, that capital depreciates completely in one period, so that investment, $z_{t}^{i}$, is just next period's capital stock, $k_{t+1}^{i}$. With this convention the relevant comovement is measured by

$$
\begin{aligned}
\operatorname{cov}\left(n x_{t}^{i}, y_{t}^{i}\right) & =\operatorname{cov}\left[y_{t}^{i}-\left(c_{t}^{i}+k_{t+1}^{i}\right), y_{t}^{i}\right] \\
& =\operatorname{var} y_{t}^{i}-\operatorname{cov}\left\{g_{i}\left(Y_{t}, \theta_{t}\right)+h_{i}\left(Y_{t}, \theta_{t}\right), f_{i}\left[h_{i}\left(Y_{t-1}, \theta_{t-1}\right), \theta_{i t}\right]\right\}
\end{aligned}
$$


where the covariance is computed using the equilibrium distribution of $\left\{\mathrm{Y}_{t}, \theta_{\mathrm{t}}\right\}$. Of particular interest is the role of persistence in $\mathrm{Y}_{\mathrm{t}}$ in the second term, but without more structure it is difficult to say more than this.

A second interpretation is based on partial depreciation. In this case gross domestic production is

$$
\mathrm{y}_{\mathrm{t}}^{\mathrm{i}}=\mathrm{f}_{\mathrm{i}}\left(\mathrm{k}_{\mathrm{t}}^{\mathrm{i}}, \theta_{\mathrm{it}}\right)-(1-\delta) \mathrm{k}_{\mathrm{t}}^{\mathrm{i}}
$$

where $\delta$ is the depreciation rate. The practical effect of this change is to introduce additional correlations between decisions made in adjacent periods. Again, it seems doubtful that much more can be said without turning to numerical methods. We turn instead to three examples, chosen to highlight particular elements of the problem.

Example 6.1. We take Brock's (1982, Section 5) example of a general equilibrium model of asset pricing with production and give it an open economy interpretation. Countries have identical utility functions, $\mathrm{u}_{\mathrm{i}}(\mathrm{c})=\log (\mathrm{c})$ and their production processes are $\mathrm{f}_{\mathrm{i}}(\mathrm{k}, \theta)+\theta \mathrm{k}^{\alpha}, 0<\alpha<1$. Shocks to technology are iid over time but may differ across countries. They have support over a finite subset of the positive orthant, but are otherwise unrestricted. The allocation functions are then

$$
\begin{aligned}
& \mathrm{C}_{\mathrm{t}}=(1-\alpha \beta) \mathrm{Y}_{\mathrm{t}} \\
& \mathrm{K}_{\mathrm{t}+1}=\alpha \beta \mathrm{Y}_{\mathrm{t}}
\end{aligned}
$$

in aggregate, and

$$
\begin{aligned}
& \mathrm{c}_{\mathrm{t}}^{\mathrm{i}}=\lambda_{\mathrm{i}} \mathrm{C}_{\mathrm{t}} \\
& \mathrm{k}_{\mathrm{t}+1}=\gamma_{\mathrm{i}} \mathrm{K}_{\mathrm{t}+1}=\gamma_{\mathrm{i}} \alpha \beta \mathrm{Y}_{\mathrm{t}} .
\end{aligned}
$$


The $\lambda_{i}$ 's are the welfare weights and are chosen to sum to one. The $\gamma_{i}$ 's also sum to one and satisfy

$$
\gamma_{i}^{1-\alpha}=E \frac{\theta_{i}}{\sum_{i} \theta_{j} \gamma_{j}^{\alpha}}, \quad t+i=1,2, \ldots, I .
$$

Brock (1982, appendix to Section 1.5) demonstrates that a solution to these equations exists.

Now consider the implications for trade dynamics. If we define GNP as $\mathrm{y}_{\mathrm{t}}^{\mathrm{i}}=\mathrm{f}_{\mathrm{i}}\left(\mathrm{k}_{\mathrm{t}}^{\mathrm{i}}, \theta_{\mathrm{it}}\right)$ and gross investment as $\mathrm{z}_{\mathrm{t}}^{\mathrm{i}}=\mathrm{k}_{\mathrm{t}+1}^{\mathrm{i}}$ then

$$
n x_{t}^{i}=y_{t}^{i}-\left[c_{t}^{i}+k_{t+1}^{i}\right]=y_{t}^{i}-\left[\lambda_{i}(1-\alpha \beta)+\gamma_{i} \alpha \beta\right] Y_{t}
$$

and

$$
\operatorname{cov}\left(\mathrm{nx}_{\mathrm{it}}, \mathrm{y}_{\mathrm{it}}\right)=\operatorname{var} \mathrm{y}_{\mathrm{it}}-\left[\lambda_{\mathrm{i}}(1-\alpha \beta)+\gamma_{\mathrm{i}} \alpha \beta\right] \operatorname{cov}\left(\mathrm{Y}_{\mathrm{t}}, \mathrm{y}_{\mathrm{it}}\right) .
$$

If the expression in brackets is large enough, we can get a negative value, at least for some countries, if domestic and world output are positively correlated. As an explanation for trade dynamics, however, it has one fatal flaw; the model implies that consumption and investment are proportional to output, so both have the same variances in percentage terms. The model therefore fails to deliver the high volatility of investment that we argued was so important in the data.

Example 6.2. We consider next a streamlined version of the Long and Plosser (1983) multisector business cycle model, interpreting their industries as countries. Unlike our earlier models, countries produce different goods. Consumers in each country are assumed to have identical homothetic preferences; as in the previous example this allows us to separate aggregate consumption from its distribution across countries. Consumers in each country i have utility function

$$
\mathrm{E}_{0} \sum_{i=0}^{\infty} \beta^{\mathrm{t}} \mathrm{u}\left(\mathrm{c}_{\mathrm{i}}^{\mathrm{i}}\right)
$$

where $c_{t}^{i}=\left(c_{1 t}^{i}, \ldots, c_{I t}^{i}\right)$ is a vector of goods and the period utility function is logarithmic: 
$\mathrm{u}\left(\mathrm{c}_{\mathrm{t}}^{\mathrm{i}}\right)=\sum_{\mathrm{j}=1}^{\mathrm{I}} \delta_{\mathrm{j}} \log \mathrm{c}_{\mathrm{jt}}^{\mathrm{i}}, \quad$ where $\delta_{\mathrm{i}} \geq 0, \quad$ and $\sum \delta_{\mathrm{i}}=1$.

Production of good $\mathrm{i}$ in period $\mathrm{t}$ uses inputs $\mathrm{k}_{\mathrm{jt}}^{\mathrm{i}}$ of every other goods $\mathrm{j}$ :

(6.5) $\mathrm{y}_{\mathrm{t}}^{\mathrm{i}}=\theta_{\mathrm{it}} \prod_{\mathrm{j}=1}^{\mathrm{I}}\left(\mathrm{k}_{\mathrm{j} \mathrm{i}}^{\mathrm{i}}\right)^{\alpha_{\mathrm{ij}}}, \quad \alpha_{\mathrm{ij}} \geq 0, \quad \sum_{\mathrm{j}} \alpha_{\mathrm{ij}}<1$.

The "capital stocks" $\mathrm{k}_{\mathrm{jt}}^{\mathrm{j}}$ last one period and are chosen of date $\mathrm{t}-1$ but the realization of the random variable $\theta_{\mathrm{it}}$ is not revealed until t. Output each period is allocated between consumption and investment:

$$
y_{t}^{i}=\sum_{j}\left[c_{j t}^{j}+k_{j j}^{i}\right]
$$

The planning problem is therefore to maximize

$$
\mathrm{W}=\sum_{\mathrm{i}=1}^{\mathrm{I}} \lambda_{\mathrm{i}}\left\{\mathrm{E}_{0} \sum_{\mathrm{i}=0}^{\infty} \beta^{\mathrm{t}} \mathrm{u}\left(\mathrm{c}_{\mathrm{i}}^{\mathrm{i}}\right)\right\}, \quad \lambda_{\mathrm{i}}>0, \quad \sum \lambda_{\mathrm{i}}=1
$$

subject to (6.5) and (6.6).

Some algebra manipulation, described in Long and Plosser, leads us to the solution:

$$
\begin{aligned}
& \mathrm{c}_{\mathrm{it}}^{\mathrm{j}}=\lambda_{\mathrm{j}} \gamma_{\mathrm{i}} \mathrm{y}_{\mathrm{t}}^{\mathrm{i}} \\
& \mathrm{k}_{\mathrm{jt}}^{\mathrm{i}}=\gamma_{\mathrm{ij}}^{*} \mathrm{y}_{\mathrm{t}}^{\mathrm{j}} .
\end{aligned}
$$

Where $\gamma_{\mathrm{i}}$ and $\gamma_{\mathrm{ij}}^{*}$ are fractions and $\Sigma_{\mathrm{i}} \gamma_{\mathrm{ij}}^{*}<1$.

The implications for comovements between, say, national output and net exports again depends on the definitions of those variables. We define real gross domestic product in country i as $\mathrm{p}_{\mathrm{i}} \mathrm{y}_{\mathrm{t}}^{\mathrm{i}}$, where $\mathrm{p}_{\mathrm{i}}$ is the price of good $\mathrm{i}$ in some base period. Without loss of generality we set $\mathrm{p}_{\mathrm{i}}=1$ so that GDP is $\mathrm{y}_{\mathrm{t}}^{\mathrm{i}}$. Aggregate consumption in country i is more complicated, since it consists of consumption of each of the I different commodities. The relative prices of these commodities vary, 
but in the national income accounts they are evaluated not at current prices but at prices in some base period. Real aggregate consumption, as measured in the national accounts, is therefore

$$
\sum_{j} p_{j} c_{j t}^{i}
$$

for some choice of base prices. For similar reasons we write real gross investment in country $\mathrm{i}$ as

$$
\sum_{j} p_{j} k_{j+1}^{i}
$$

and net exports as

$$
n x_{t}^{i}=y_{t}^{i}-\sum_{j} P_{j}\left[c_{j t}^{i}+k_{j+1}^{i}\right]=y_{t}^{i}-\sum_{j} P_{j}\left[\lambda_{i} \gamma_{i}+\gamma_{i j}^{*}\right] y_{i}^{j} .
$$

The covariance between output and net exports is

$$
\operatorname{cov}\left(n x_{t}^{i}, y_{t}^{i}\right)=\operatorname{var} y_{t}^{i}-\sum_{j} p_{j}\left[\lambda_{i} \gamma_{j}+\gamma_{i j}^{*}\right] \operatorname{cov}\left(y_{t}^{j}, y_{t}^{i}\right)
$$

which has many of the features of Brock's example. In particular it relies on covariances between domestic and foreign output, and only avoids exact equality between percentage variations in consumption and investment by introducing aggregation problems.

Neither of these examples is particularly illuminating. In our opinion they illustrate that the simple functional forms that serve us so well in other contexts do not help us here. The next example does permit us some analytical results, by assuming there is no aggregate uncertainty.

Example 6.3. Consider an economy facing a fixed rate of interest rate, $(1-\beta) / \beta$. The fixed rate of interest could reflect constant world output, but whatever its source it implies constant domestic consumption. All variations in net exports are driven by investment. Consumers in this economy solve the problem

$$
\max _{\left\{c_{\mathrm{t}}\right\}} \mathrm{E}_{0} \sum_{\mathrm{t}=0}^{\infty} \beta^{\mathrm{t}} \mathrm{u}\left(\mathrm{c}_{\mathrm{t}}\right)
$$

subject to 


$$
\sum_{t=0}^{\infty} \beta^{t} c_{t} \leq M
$$

where $\mathrm{M}$ is the value of all claims held by consumers in the country. The first order conditions imply constant consumption. Firms face the problem

$$
\max _{\left\{k_{\mathrm{t}}\right\}} \mathrm{E}_{0} \sum_{\mathrm{t}=0}^{\infty} \beta^{\mathrm{t}}\left[\mathrm{f}\left(\mathrm{k}_{\mathrm{t}}, \theta_{\mathrm{t}}\right)-\beta^{-1} \mathrm{k}_{\mathrm{t}}\right]
$$

where $\theta$ is first-order Markov. The first-order condition are

$$
\beta \mathrm{E}_{\mathrm{t}}\left\{\partial \mathrm{f}\left(\mathrm{k}_{\mathrm{t}}, \theta_{\mathrm{t}}\right) / \partial \mathrm{k}_{\mathrm{t}}\right\}=1, \quad \mathrm{t}=0,1,2, \ldots
$$

Profits from production may or may not be included in M.

We now specialize the model and point out the importance of the curvature of $f$ and the persistence of $\theta$ in generating large fluctuations in $\mathrm{k}$. Clearly the covariances with world output that were so important in earlier examples play no role here. Let $\mathrm{f}(\mathrm{k}, \theta)=\theta \mathrm{k}^{\alpha}, 0<\alpha<1$, and let $\log \theta$ be $\mathrm{AR}(1)$ with normal disturbances:

$\log \theta_{\mathrm{t}+1}=\rho \log \theta_{\mathrm{t}}+\epsilon_{\mathrm{t}+1}$

$\left\{\epsilon_{\mathrm{t}}\right\} \sim \mathrm{NID}(0, \mathrm{v})$. Then $\mathrm{k}_{\mathrm{t}+1}=\mathrm{g}\left(\theta_{\mathrm{v}}\right)$, where

$$
\mathrm{g}(\theta)=\frac{\exp [(\rho+\mathrm{y} / 2) /(1-\alpha)]}{(\alpha \beta)^{1 /(1-\alpha)}}
$$

From the dynamics of $\theta$ we can determine the dynamics of $\mathrm{k}$ and $\mathrm{y}$ and hence the comovements of $\mathrm{y}$ and nx:

$$
\operatorname{cov}(\mathrm{nx}, \mathrm{y})=\operatorname{var} \mathrm{y}-\operatorname{cov}(\mathrm{k}, \mathrm{y})
$$

To a first approximation we can write this as

$$
\operatorname{cov}(\mathrm{nx}, \mathrm{y})=\left[\mathrm{f}_{\theta}^{2}-\mathrm{f}_{\theta} \mathrm{g}_{\theta}\right] \operatorname{var} \theta
$$

so the covariance is negative if and only if $g_{\theta}>f_{\theta}$. If we evaluate this at the steady state value of $k$, 


$$
\mathrm{g}_{\theta}=\mathrm{g}(\theta) \rho /(1-\alpha)
$$

and $\mathrm{g}_{\theta}>\mathrm{f}_{\theta}$ if

$$
1-\alpha>\text { p. }
$$

Obviously $\rho$ must be positive. The inequality also has the feature that, for any choice of $\alpha$, there exists a value of $\rho<1$ such that the condition holds. The larger is $\alpha$, the large $\rho$ must be. We see therefore that persistent shocks and production functions without much curvature are conducive to generating the large fluctuations in investment apparent in the data.

\section{Final Remarks}

We have made a case for investment-driven trade dynamics in the spirit of Sachs (1981). At this point we view it as a reasonable working hypothesis, but clearly more work will need to be done before we can compare it to alternatives. We think empirical work on other countries should be done to see if the regularities of American data hold more generally. On the theoretical side, we think the difficulty of deriving analytical results in Section 6 is a strong argument in favor of quantitative methods like those of Kydland and Prescott (1982). We leave both for another day. 


\section{References}

Breeden, Douglas, and Litzenberger, Robert. 1978. Prices of state-contingent claims implicit in option prices. Journal of Business 51 (October): 621-51.

Brock, William. 1982. Asset prices in a production economy. In The economics of information and uncertainty, ed., J. J. McCall (Chicago: University of Chicago Press).

Feldstein, Martin, and Horioka, Charles. 1980. Domestic saving and international capital flows. Economic Journal 90 (June): 314-29.

Frenkel, Jacob, and Razin, Assaf. 1985. Government spending, debt, and international economic interdependence. Economic Journal 95 (September): 619-36.

Helpman, Elhanan, and Razin, Assaf. 1982. Dynamics of a floating exchange rate regime. Journal of Political Economy 90 (August): 728-59.

. 1984. The role of saving and investment in exchange rate determination under alternative monetary mechanisms. Journal of Monetary Economics 13 (May): 307-25.

. 1985. Floating exchange rates with liquidity constraints in financial markets. Journal of International Economics 19, 99-117.

Hodrick, Robert, and Prescott, Edward C. 1978. Postwar U.S. business cycles: An empirical investigation. Mimeo.

Kehoe, Patrick J. 1986. Notes on macroeconomics in a world economy. Mimeo (April).

Kydland, Finn, and Prescott, Edward C. 1982. Time to build and aggregate fluctuations. Econometrica 50 (November): 1345-70.

Long, John, and Plosser, Charles. 1983. Real business cycles. Journal of Political Economy 91 (February): 39-69. 
Lucas, Robert; Prescott, Edward C.; and Stokey, Nancy. 1986. Dynamic competitive analysis (Cambridge: Harvard University Press, forthcoming).

Obstfeld, Maurice. 1986. Capital mobility in the world economy: Theory and measurement. Carnegie-Rochester Conference Series on Public Policy 24, 55-104.

Prescott, Edward C. 1983. Can the cycle be reconciled with a consistent theory of expectations: A progress report on business cycle theory. Working Paper 239. Federal Reserve Bank of Minneapolis (June).

1986. Theory ahead of business cycle measurement. Staff Report 102. Federal Reserve Bank of Minneapolis (February); forthcoming in Carnegie-Rochester.

Sachs, Jeffrey. 1981. The current account and macroeconomic adjustment in the 1970s. Brookings Papers on Economic Activity 1, 201-68.

Sargent, Thomas. 1986. Dynamic macroeconomic theory (Cambridge: Harvard University Press). Stockman, Alan, and Svensson, Lars. 1985. Capital flows, investments, and exchange rates. Working Paper 1598. National Bureau of Economic Research (April). 
Table 1

High-Frequency Comovements of Selected Variables With GDP*

(Detrended Data for the United States: $1954: 1$ to $1986: 2$ )

\begin{tabular}{|c|c|c|c|c|c|c|c|c|c|c|c|c|c|c|c|}
\hline \multirow[b]{2}{*}{ Variable } & \multirow{2}{*}{$\begin{array}{c}\text { Mean } \\
\text { Share of } \\
\text { GDP }\end{array}$} & \multirow[b]{2}{*}{$\begin{array}{l}\text { Standard } \\
\text { Deviation }\end{array}$} & \multicolumn{13}{|c|}{ Cross Correlations With GDP } \\
\hline & & & -6 & -5 & -4 & -3 & -2 & -1 & 0 & 1 & 2 & 3 & 4 & 5 & 6 \\
\hline Gross Domestic Product & 1.00 & $2.1 \%$ & -.09 & .04 & .22 & .43 & .66 & .86 & 1.00 & .86 & .66 & .43 & .22 & .04 & -.09 \\
\hline Consumption & .61 & 1.6 & .15 & .28 & .42 & .55 & .69 & .79 & .82 & .65 & .45 & .24 & .03 & -.15 & -.28 \\
\hline Nondurables and Services & .54 & 1.1 & .09 & .21 & .36 & .49 & .63 & .74 & .78 & .65 & .50 & .33 & .14 & -.02 & -.15 \\
\hline Durables & .07 & 6.2 & .19 & .29 & .40 & .51 & .64 & .71 & .74 & .55 & .33 & .09 & -.13 & -.30 & -.40 \\
\hline Investment & .17 & 9.6 & .00 & .11 & .26 & .44 & .62 & .79 & .90 & .75 & .52 & .26 & .03 & -.16 & -.29 \\
\hline Nonresidential Fixed & .11 & 6.0 & -.33 & -.24 & -.10 & .07 & .32 & .58 & .82 & .89 & .86 & .73 & .55 & .34 & .15 \\
\hline Other & .06 & & & & & & & & & & & & & & \\
\hline Government Purchases & .23 & 2.8 & .02 & .04 & .04 & .05 & .07 & .09 & .13 & .14 & .14 & .15 & .19 & .21 & .21 \\
\hline Net Exports & .00 & 7.3 & -.51 & -.56 & -.57 & -.53 & -.45 & -.36 & -.26 & -.13 & .05 & .24 & .41 & .52 & .54 \\
\hline Exports & .08 & 6.1 & -.52 & -.49 & -.42 & -.27 & -.06 & .19 & .40 & .54 & .59 & .60 & .59 & .51 & .38 \\
\hline Imports & .08 & 5.9 & .09 & .18 & .27 & .37 & .50 & .65 & .74 & .72 & .55 & .33 & .10 & -.12 & -.27 \\
\hline Federal Government Deficit & .01 & 5.8 & .31 & .21 & .08 & -.08 & -.31 & -.54 & -.73 & -.75 & -.66 & -.51 & -.34 & -.18 & -.04 \\
\hline Expenditures & .20 & 3.1 & .06 & .05 & .03 & -.02 & -.09 & -.17 & -.25 & -.29 & -.28 & -.20 & -.09 & .01 & .09 \\
\hline Revenues & .19 & 4.6 & -.35 & -.23 & -.08 & .09 & .33 & .56 & .75 & .75 & .64 & .50 & .36 & .23 & .12 \\
\hline
\end{tabular}

*With two exceptions, variables have been detrended by taking logarithms and applying the Hodrick-Prescott filter. The exceptions are net exports and the Federal government deficit, which are the differences between their filtered components. Cross correlations are for GDP at the given lag $(-6,-5, \ldots, 6)$ and the contemporaneous value of the designated variable. 
Table 2

High-Frequency Comovements With Net Exports

\begin{tabular}{|c|c|c|c|c|c|c|c|c|c|c|c|c|c|}
\hline \multirow[b]{2}{*}{ Variable } & \multicolumn{13}{|c|}{ Cross Correlations With Net Exports } \\
\hline & -6 & -5 & -4 & -3 & -2 & -1 & 0 & 1 & 2 & 3 & 4 & 5 & 6 \\
\hline Net Exports & -.12 & .05 & .25 & .45 & .66 & .83 & 1.00 & .83 & .66 & .45 & .25 & .05 & -.12 \\
\hline $\begin{array}{l}\text { Consumption } \\
\text { Nondurables and Services } \\
\text { Durables }\end{array}$ & $\begin{array}{l}.29 \\
.26 \\
.27\end{array}$ & $\begin{array}{l}.23 \\
.22 \\
.21\end{array}$ & $\begin{array}{l}.13 \\
.13 \\
.11\end{array}$ & $\begin{array}{r}.00 \\
.03 \\
-.03\end{array}$ & $\begin{array}{l}-.12 \\
-.08 \\
-.15\end{array}$ & $\begin{array}{l}-.24 \\
-.19 \\
-.25\end{array}$ & $\begin{array}{l}-.32 \\
-.28 \\
-.31\end{array}$ & $\begin{array}{r}-.34 \\
-.31 \\
.31\end{array}$ & $\begin{array}{l}-.36 \\
-.35 \\
-.30\end{array}$ & $\begin{array}{l}-.37 \\
-.37 \\
-.30\end{array}$ & $\begin{array}{l}-.34 \\
-.34 \\
-.27\end{array}$ & $\begin{array}{l}-.30 \\
-.30 \\
-.24\end{array}$ & $\begin{array}{l}-.24 \\
-.26 \\
-.17\end{array}$ \\
\hline $\begin{array}{l}\text { Investment } \\
\text { Nonresidential Fixed } \\
\text { Other }\end{array}$ & $\begin{array}{l}.43 \\
.42\end{array}$ & $\begin{array}{l}.38 \\
.46\end{array}$ & $\begin{array}{l}.29 \\
.43\end{array}$ & $\begin{array}{l}.15 \\
.36\end{array}$ & $\begin{array}{l}.00 \\
.25\end{array}$ & $\begin{array}{r}-.15 \\
.13\end{array}$ & $\begin{array}{r}-.26 \\
.01\end{array}$ & $\begin{array}{l}-.30 \\
-.08\end{array}$ & $\begin{array}{l}-.32 \\
-.16\end{array}$ & $\begin{array}{l}-.33 \\
-.23\end{array}$ & $\begin{array}{l}-.33 \\
-.30\end{array}$ & $\begin{array}{l}-.31 \\
-.34\end{array}$ & $\begin{array}{l}-.26 \\
-.35\end{array}$ \\
\hline Government Purchases & -.04 & -.05 & -.05 & -.06 & -.02 & -.01 & -.01 & -.00 & -.01 & .00 & .00 & .00 & .03 \\
\hline $\begin{array}{l}\text { Federal Government Purchases } \\
\text { Expenditures } \\
\text { Revenues }\end{array}$ & $\begin{array}{r}-.49 \\
-.27 \\
.43\end{array}$ & $\begin{array}{r}-.55 \\
-.28 \\
.50\end{array}$ & $\begin{array}{r}-.56 \\
-.30 \\
.50\end{array}$ & $\begin{array}{r}-.48 \\
-.25 \\
.43\end{array}$ & $\begin{array}{r}-.32 \\
-.17 \\
.29\end{array}$ & $\begin{array}{r}-.14 \\
-.05 \\
.14\end{array}$ & $\begin{array}{r}.04 \\
.05 \\
-.01\end{array}$ & $\begin{array}{r}.18 \\
.18 \\
-.10\end{array}$ & $\begin{array}{r}.25 \\
.23 \\
-.16\end{array}$ & $\begin{array}{r}.37 \\
.30 \\
-.27\end{array}$ & $\begin{array}{r}.47 \\
.34 \\
-.36\end{array}$ & $\begin{array}{r}.54 \\
.38 \\
-.43\end{array}$ & $\begin{array}{r}.49 \\
.34 \\
-.39\end{array}$ \\
\hline
\end{tabular}

Notes: See Table 1. 